Jo Spaans

\title{
PUBLIC OPINION OR RITUAL CELEBRATION OF CONCORD? POLITICS, RELIGION AND SOCIETY IN THE COMPETITION BETWEEN THE CHAMBERS OF RHETORIC AT VLAARDINGEN, 1616
}

(Judith Pollmann and Andrew Spicer (eds.), Public Opinion and Changing Identities in the Early Modern Netherlands. Essays in Honour of Alastair Duke, Leiden, Brill, 2006, 189-209.)

In the summer of 1616 fifteen chambers of rhetoric - lay societies which composed and performed erudite vernacular plays on formal occasions - met for a festival in Vlaardingen, a port and fishing town on the Meuse just west of Rotterdam. The Vlaardingen chamber, The Oaktree (De Akerboom) had invited sister-chambers from a number of towns and villages to come and compete in a rhetorical display. The occasion lasted for several days. It began with the formal reception of the visiting chambers, who processed in, wearing their stage-costumes. They presented their hosts with ornamental shields emblazoned with their coat of arms, accompanied by a suitable poetic greeting, which was answered with a similar form of welcome by the brothers of The Oaktree. Over the next few days the chambers staged morality plays and held contests in the recitation of poems, both prepared and extempore, developing a theme set by their host. A jury awarded prizes for various aspects of performance, presentation and content, and the festival was concluded by a formal closing ceremony.

Festivals of this kind were obviously not only a literary competition but also an occasion for public festivity. The Reformed Church was highly critical of these public performances and put pressure on secular authorities to prohibit them altogether. The plays usually had a moral content, expressed in religious terms sometimes drawing upon Bible stories for their subject matter. The Church resented this use of theologically sensitive material, as the popular format of a morality play almost inevitably led to deviations from established orthodoxy. Moreover, the Church condemned performing on Sundays, the travesty of male players impersonating female characters and the general incitement to frivolity that the theater represented. Even the activities of the rhetoricians in the privacy of their chambers were deeply distrusted, as they provided a forum where Reformed and non-Reformed exchanged playful verses on matters of political, social and moral relevance over drinks and tobacco. ${ }^{1}$

Recent research, however, has convincingly shown that the activities of the chambers of rhetoric also had more serious aspects. Besides venues for male conviviality they functioned as popular academies, providing adult men with a formalized education in the vernacular linguistic skills, both written and oral, that were necessary for all those

\footnotetext{
${ }^{1}$ F.C. van Boheemen and Th.C.J. van der Heijden, De Hollandse rederijkers vanaf de middeleeuwen tot het begin van de achttiende eeuw. Bronnen en bronnenstudies (Delft, 1999).
} 
aspiring to public office. ${ }^{2}$ These skills were honed in the regular meetings of the chambers under the patronage of local magistrates and in the more controversial locally performed public plays and supra-local festivals. Until well into the eighteenth century the chambers of rhetoric provided this educational role, despite the misgivings of the Church. Recently they have even been credited with preparing the way for a modern public sphere, in forming public opinion, both among the members of the chamber and in the audience. It has been claimed that the plays presented a varity of possible points of view on often controversial issues and intended to offer the audience food for thought and for further discussion.

This view has recently been advocated by Arjan van Dixhoorn. His thesis has demonstrated that the founding of new chambers and supra-local festivals noticeably coincided with periods of heightened tension, such as the penetration of Protestant thought into the Netherlands, the Revolt, the discussions on humanist reforms in poor relief and the Twelve Years' Truce. ${ }^{3}$ Dixhoorn's view is in line with the recent work of Willem Frijhoff and Marijke Spies, who coined the term 'discussion culture' to describe the cultural formation of the Republic. Its decentralised political structure with an abundance of corporate bodies on all levels of government and administration, demanded constant rounds of consultation and the building of consensus. ${ }^{4}$ Speialists on Dutch Renaissance theatre, moreover, identify specific partisan positions in individual plays or festivals. ${ }^{5}$

The Vlaardingen Chamber invited participants in the 1616 festival to present a morality play on the question 'Which necessary measures should be taken for the common good of people and country?' Beside plays, poems had to be delivered on what seems to be an unrelated and uncontroversial topic: 'He who raises his children well and properly, what do they, once grown up, owe him in return?' At first sight the theme for the plays does indeed fit Van Dixhoorn's thesis. The year 1616 was one of mounting tension. The performances might be expected to reflect the political and religious opinions of their various authors and/or the elites of their home cities, presenting the audience with a range of arguments that lent themselves to further discussion and in relation to which each person could formulate a position of his or her own. The published scripts of the plays, however, raise seriously questions about

\footnotetext{
${ }^{2}$ Above all Arjan van Dixhoorn, Lustige geesten, Rederijkers en hun kamers in het publieke leven van de Noordelijke Nederlanden in de vijftiende, zestiende en zeventiende eeuw (n.p., 2004).

${ }^{3}$ Van Dixhoorn, Lustige geesten, p. 366-388, cf. Marijke Spies, 'Rederijkers in beroering: religie en politiek bij de Hollandse rederijkers in de eerste decennia van de zeventiende eeuw', in: Fred de Bree, Marijke Spies en Roel Zemel, 'Teeckenrijcke Woorden' voor Henk Duits. Opstellen over literatuur, toneel, kunst en religie, meest uit de zestiende en zeventiende eeuw (Amsterdam and Münster, 2002), p. 59-76.

${ }^{4}$ Willem Frijhoff and Marijke Spies, 1650. Bevochten eendracht (Den Haag, 1999), p. 218-224.

${ }^{5}$ Marijke Spies, 'Rederijkers in beroering: religie en politiek bij de Hollandse rederijkers in de eerste decennia van de zeventiende eeuw', in: Fred de Bree, Marijke Spies en Roel Zemel, 'Teeckenrijcke Woorden' voor Henk Duits. Opstellen over literatuur, toneel, kunst en religie, meest uit de zestiende en zeventiende eeuw (Amsterdam and Münster, 2002), p. 59-76, Mieke B. Smits-Veldt, 'Menenius Agrippa op het rederijkerstoneel in Vlaardingen en Amsterdam', in: Karel Porteman en Kurt Erich Schöndorf (eds.), Liber amicorum prof. dr. Kare Langvik-Johannessen (Leuven, 1989), p. 185-197.
} 
these assumptions. The scripts are ambiguous at best, and can hardly be credited with the viewpoints that, with hindsight, we know characterised the opposing parties. ${ }^{6}$

This article will analyse the published texts on three related questions. The first concerns the representation of the political and religious problems that confronted the Dutch Republic in 1616. These cluster around the relative merits of war and peace, the rivalry between stadholder Maurice and the landsadvocaat Oldenbarnevelt, and the associated religious controversies. Secondly, the article will consider the perception of an ideal society that emerges from these plays and poems. Finally it will question the assertion made in recent studies that plays contributed to a public debate, or even to the formation of a climate of public opinion?

\section{The Twelve Years' Truce: Half a Peace and Uneven Profits}

By 1616 therer was increasing tension in the Dutch Republic over the political and religious controversies, which would bring the country to the brink of civil war. First, the Twelve Years' Truce (1609-1621) in the protracted war against Spain brought to the fore the question of the precise relationship between the provincial States and the States General, which was poorly defined, while the position of the stadholder remained ambiguous. Who was to decide whether to resume the war after 1621 or to look for lasting peace? This was a complicated issue as the provinces that constituted the Republic, and the powerful cities that dominated the States of Holland in particular, had diverging views on this matter,.

The economic arguments that had led to the Truce in the first place were still as valid as they had been in 1609. The war had bled the economies of both protagonists. Spanish trade embargoes hampered trade between the Baltic and the Iberian Peninsula, which was the mainstay of Dutch overseas commerce. The lucrative colonial venture of the Dutch East India Company clashed with Spanish interests in the East, as did plans to form a Dutch West Indian Company in the Caribbean. The landsadvocaat of Holland, Johan van Oldenbarnevelt, through patient but determined diplomacy, agreed with Spain on a truce for twelve years, for a very low price. The Truce lifted the embargo on the north-south route. Moreover it offered respite to the land-provinces, which had suffered most heavily from war damage inflicted upon the land and its population by battles and sieges, the passage of armies and marauding soldiers. In return, the Republic merely promised not to expand its trade activities in the East and West Indies, denying the wishes of the king of Spain for concessions towards improving the position of the Catholic Church in the Republic. A continuation of the war would have been to the advantage of Zeeland and some Holland towns, but the Truce benefited all those involved in colonial trade, and the land-provinces.

The stadholder, Count Maurice of Nassau, supported by his cousin Louis of Nassau, stadholder of the northern provinces, had always advocated a continuation of the war which aligned the Republic with England. This policy met with increasing support

\footnotetext{
${ }^{6}$ Vlaerdings Redenryck-bergh, met middelen beplant, die noodigh sijn 't Gemeen, en vorderlijck het landt (Amsterdam 1617), references between () are to the pages of this edition.
} 
from the States General. Th landsadvocaat, on the other hand, supported by a powerful party in the Estates of Holland, favoured the conclusion of peace and an alliance with France as most favoured European power. For all parties a Truce was a halfway solution, although none could deny that it brought the Republic considerable advantages in the short term. The Republic had gained international prestige because it had bought the Truce from its formidable enemy for such a low price. Prosperity returned, although its benefits were unevenly divided. ${ }^{7}$

The plays reflect all these dilemmas. For most of them, the Revolt against Spain is the backdrop of the action. In some form they all comment on the contemporary political and economic situation of the country, and the relative advantages and disadvantages of peace, truce or war. The first half of the play performed by the chamber of Kethel, for example, presents a dialogue between Monarchy, representing the king of Spain, with his advisers Tyranny, Force, Deceit and Dishonest Inquiry. Monarchy brags about his world-spanning dominion, marred only by his failure to subdue the Republic. He describes how this irksome little nation robs him of the profit in colonial trade which he so sorely needs to pay his armies, utterly frustrating his hopes of eventual victory. The advisers counsel their king to agree to a Truce, with the intent to deceitfully attack when the Dutch are off their guard.

The second half of Kethel's play shows Freedom of the Land, representing the Republic, in conference with her councillors Constant Prudence and Vigilance. The proposed Truce is here decried as a mere semblance of peace, which offers no guarantee against the treachery of a vengeful enemy. How to choose between a ruinous war or a partial peace, which moreover will incite all sorts of sectaries to divide the population? She briefly considers the benefits of open war, but is moved by advisers, with allegorical names like Profound Wisdom, Common Weal, True Teaching and Fear of God, to pursue lasting peace. This can be attained when a prudent regime, concludes the chamber of Kethel, when a prudent regime, under a unified government, faithfully guides a godfearing people. ${ }^{8}$

Not all chambers envisioned such a peaceful solution to the Republic's problems. Amsterdam's The Sweet-Briar (De Egelantier) rejects any compromise with the enemy which limits industry and the freedom of trade. It sings an unabashed panegyric of war: true Batavians are in their element when the drum rolls, the trumpet rings out, the horses are bridled and soldiers march as far as the eye can see.

According to the Amsterdam chamber, what was best for people and country was to pray for divine blessing while preparing for war. Even so, a precondition for success was concord at the home front. ${ }^{9}$

The protagonist of this play is Ruler, who is counseled by a succession of advisers on good government. They argue that a good prince abhors tyranny and venality, protects

\footnotetext{
${ }^{7}$ Jonathan Israel, The Dutch Republic. Its Rise, Greatness and Fall 1477-1806 (Oxford, 1995), p. 399477. The perspective of the main protagonists in J.J. den Tex, Oldenbarnevelt, 5 vols. (Haarlem, 19601972), vol. 2-3 and A.Th. van Deursen, Maurits van Nassau. De winnaar die faalde (Amsterdam, 2000), p. 201-278.

${ }^{8}$ Redenryck-bergh, fol. Ee2v, Ff1v, Ff3v-4r.

${ }^{9}$ Redenryck-bergh, fol. M3v-4r.
} 
religion, is virtuous and just, capable and a man of his word. He shows self-restraint, and prevents discord among the ruled arising from deceit, hatred or distrust of government. Most importantly, he must have the courage to be firm. At the same time he can never afford to lose his subjects' love towards him. The entire play never even mentions the war against Spain, the Truce or its approaching end. The message of the play remains ambiguous: it could be read as an argument in favour of resuming the war against Spain with God's blessing, or as the truism that a good prince should not hesitate to take up arms where needed - leaving open the question whether this was such a moment of need.

The play of the chamber of Gorcum is equally ambiguous about the merits of war, but applies its reflections more directly to current affairs. Here a spectacular part is reserved for the war god Mars. When the main character, Nation, complains it is tired of war, Vigilance and Suspicion recall the excellent services of Mars in the war against Spain. They advise Nation to call in the help of Mars again, now that tensions are mounting in the country itself, rendered more dangerous as Spain's armies are mobilised just across the border for an intervention in the contested succession of Jülich and Cleves. ${ }^{10}$

At the same time, however, the war god is courted by Conceited Mind and Unrest. In what must have been a spectacular scene, these two shady characters make Mars perform a magic ritual to conjure up Discord from the deepest regions of Hell. ${ }^{11}$ Good Government promptly sends Vigilance to remind Mars of his long-standing friendship with Nation, to persuade him to preserve the country against external and internal enemies, and to restrain him from unleashing civil war. High Authority and Good Government symbolically avert these dangers by disarming Mars and tying one of his arms behind his back, leaving the other one free to protect Nation. ${ }^{12}$ In this way the Gorcum chamber, like the Amsterdam Sweet-Briar, avoids pleading openly for resumption of the war. At the same time it declares that war against an external enemy has its proper use, and calls for concord at the home front.

The chamber from the port of Rotterdam also emphasized the positive sides of war. Where wars usually bring destruction, by God's grace it has made the Dutch Republic flourish, and it has increased both its wealth and its international standing. The Rotterdam chamber praised the prosperity, military strength, and world-wide trade networks of the Republic, that together made it a world power, despite the war. The one blemish on this splendid performance was the recent discord that augured no good in view of the dangers inherent in its current position. A truce, after all, was only half a peace, and the god of war (shown sleeping on the stage) remained anything but harmless. ${ }^{13}$

The Amsterdam chamber The White Lavender (Het Wit Lavendel), specified some economic aspects of this internal discord. Its play depicts a dethroned and somewhat

\footnotetext{
${ }^{10}$ Redenryck-bergh, fol. Tt2v, cf. Israel, Dutch Republic, p. 407.

${ }^{11}$ Redenryck-bergh, fol. Tt4r-v.

${ }^{12}$ Redenryck-bergh, fol. Xx2v.

${ }^{13}$ Redenryck-bergh, fol. Hh3v, Kk1r-v.
} 
grumpy Mars. He blames the king of Spain, who, despite his otherwise admirable bloodthirstiness, has let the Dutch get away with a truce, which will not profit either side: both have struck a bad deal. In a series of sketches, a farmer, a burgher of independent means, and a group of city dwellers comment its mixed blessings. The farmer and the man of means prosper, but the city dwellers suffer from a decline in manufacture. They have a hard time making ends meet. Moreover, there is division in the Church - represented on stage by the Devil sowing the seeds of discord, while the people are asleep. ${ }^{14}$ For all their astute diagnosis, the brothers of The White Lavender propose a remarkably unpolitical solution to the question posed by their hosts. They counsel concord, peace and love in accordance with God's will. ${ }^{15}$

On the whole these five chambers each show considerable ambiguity about the relative merits of war or Truce and most of them do not even draw upon this theme. Delft, Gouda and Nootdorp straightforwardly plead for love and concord. Delft compares the Republic with the ancient Greeks, who through concord, piety and other republican virtues succeeded in beating off the Persian invasion under the mighty King Xerxes. The play by the chamber of Gouda asserts that God will continue the support he has shown the Republic in the war against Spain as long as concord is not broken. Nootdorp does not even need to make an explicit reference to the political situation to deliver a comparable message. The chambers represented at the Vlaardingen festival in 1616 overwhelmingly answer the political question of The Oaktree in the sense that restoration of love and harmony are the most necessary measures to be taken on behalf of people and country.

The Portrayal of stadholder Maurice and landsadvocaat Oldenbarnevelt in the Plays

In their emphasis on the virtues of peace and concord the chambers actually conformed to official state policy. In 1616 no official decision had yet been taken about what to do after the Truce expired - and in fact this remained an open question even in $1621 .{ }^{16}$ It was no secret that the stadholder and the landsadvocaat had their differences of opinion on constitutional matters and foreign policy. Both had, however, so far avoided open confrontation, and presented a united front. Provincial States and city magistrates might have their preferences for one or the other, but most kept their own counsel. ${ }^{17}$

Two chambers at the Vlaardingen contest allowed their preferences to show in the plays they staged. The character appears in the play performed by Maasland, where together with Nobility, Knights and Cities he provides advice to the character

\footnotetext{
${ }^{14}$ Redenryck-bergh, fol. O1r, O2r and O3v-V1r.

${ }^{15}$ Redenryck-bergh, fol. Q2r.

${ }^{16}$ J.J. Poelhekke, T'uytgaen van den Trêves. Spanje en de Nederlanden in 1621 (Groningen, 1960).

${ }^{17} \mathrm{~S}$. Groenveld, Evidente factiën in den staet. Sociaal-politieke verhoudingen in de 17 -eeuwse Republiek der Verenigde Nederlanden (Hilversum 1990), p. 14-32.
} 
Country, a representation of the States of Holland. Country is riven by discord. ProSpanish Counsel proposes to return to the obedience of the king of Spain, as only a monarchy can wield the power needed to enforce strict laws and regulations, and so restore tranquility. When Country shows some susceptibility to these arguments, Lands' Advocaat forcefully rejects them. Force has proven to be totally counterproductive, and has led to revolt and war in the first place..$^{18}$ In this play Lands' Advocaat is the only figure with a strong and convincing position, squarely defending the constitution of the Republic, whereas Nobility, Knights and Cities seem to waver and Country is desperate. The stadholder is not mentioned at all. The answer that it finally formulated on the Vlaardingen theme, however, gave pride of place, not to statesmen, but to Fear of God — not a religious party, but 'the beginning of all wisdom' - which will lead the people to obedience to those set in authority above them and to love of their neighbours. ${ }^{19}$

The chamber of Gorcum briefly mentions Oldenbarnevelt as the architect of the Truce, this half-peace. In contrast, it presents the Princes of Orange as the true shepherds of the country. Lamentably William the Silent was treacherously murdered, but his House has produced a new hero, a splendid war leader, who with God's help leads the Republic to victories that are sung all over the world. The character High Authority symbolically offers him a sword with which to quell the internal dissension, and exhorts him to extend impartial judgement over rich and poor. ${ }^{20}$ The play thus echoes sentiments that would recur in periodic Orangist opposition movements against the power of the urban regent factions. The latter were perceived as only looking after their own profit, to the exclusion of all others, whereas only the stadholders were in a position to protect the common interests of all inhabitants. Unlike Maasland, Gorcum seems to advocate a sovereignty vested in the States General, represented in the play by High Authority, and the stadholder as their executive arm, bypassing the claims of the Provincial States.

Most chambers do not mention the rivalry between statesmen or the high colleges of State at all. The White Carnations (De Witte Angieren) of Haarlem advocates harmonious collaboration between stadholder and States, as they are both bound by oath to maintain its laws and privileges. Others limited themselves to a more general plea that each should do his duty in the positions to which they had been called. ${ }^{21}$

\section{Remonstrants and Counter-remonstrants}

The discussion over the constitution and the political future of the Republic was exacerbated by growing dissension in the public Church over the interpretation of its

\footnotetext{
${ }^{18}$ Redenryck-bergh, fol. D1v.

${ }^{19}$ Redenryck-bergh, fol. E1r.

${ }^{20}$ Redenryck-bergh, fol. Tt3v, Vv3r, Vv4r.

${ }^{21} \mathrm{Cf}$. below: The ideal society.
} 
Reformed confession of faith. The Dutch Reformation had been a political Reformation. The new regime that established itself in the wake of the Revolt relied heavily on groups that had rallied to a Reformed style of Protestantism. Consequently, the Reformed Church was established as the public Church in each of the United Provinces. ${ }^{22}$ Theologically this Reformed heritage had initially been somewhat fluid. ${ }^{23}$ The first generation of Reformed ministers had focused on the differences between Protestantism and Roman Catholicism and the organisation of a new Church. The generation that graduated from the Dutch universities around the turn of the seventeenth century had ambitions to develop Reformed doctrine and define it more sharply. These younger men were the products of an academic culture of formalized disputation, which had taught them to examine and defend the tenets of their faith in the light of biblical testimony. Unavoidably this led to discussions that touched on the foundations of Reformed theology.

The theological controversies not only added to a given conflict of interests, but are often seen as the most explosive issue. They centered on election and reprobation. ${ }^{24}$ Standard Reformed doctrine states that God is both merciful and just. Although, as a consequence of Adam's sin, the entire human race is tainted, in His mercy God delivers from eternal damnation all those He elects to save in Jesus Christ, irrespective of their merits. Justly, He leaves other to the eternal punishment they deserve because of their sins. ${ }^{25}$ In the seventeenth century theological inquiry could and did push further, asking why, if man's will is unfree and God is merciful, He elects some but rejects others. In his Institutes of the Christian Religion, Calvin himself defended the freedom of academic theological speculation, but warned against vain curiosity, moving beyond what is biblically defensible on this topic. For him, digging deeper than what God has seen fit to reveal in Scripture amounted to blasphemy. ${ }^{26}$ Following these guidelines, around 1600, both in the Republic and abroad, Reformed theologians speculated on the logical sequence in God's eternal decrees.

The resulting theological opinions can be broadly divided into three main streams. The so-called infralapsarian position stated that God had foreseen Adam's fall before Creation, had then decided to elect some and reject others, without taking account of their acts, and finally decided to let His Son atone for the sins of the elect on the Cross. The somewhat sterner supralapsarian argument held that God had first and

\footnotetext{
${ }^{22}$ Joke Spaans, 'Catholicism and Resistance to the Reformation in the Northern Netherlands', in: Philip Benedict a.o. (eds.), Reformation, Revolution and Civil War in France and the Netherlands 1555-1585 (Amsterdam, 1999), p. 149-163.

${ }^{23}$ W. Nijenhuis, 'De publieke kerk, veelkleurig en verdeeld, bevoorrecht en onvrij', in: D.P. Blok a.o. (eds.), Algemene Geschiedenis van Nederland, 15 vols. (Haarlem, 1977-1983), vol. 6, p.325-343.

${ }^{24}$ Cf. Ivo Schöffer, 'De crisis van de jonge Republiek 1609-1625', in: J.A. van Houtte a.o. (eds.), Algemene Geschiedenis der Nederlanden, 13 vols. (Antwerp, 1949-1958), vol. 6, p. 1-60; A.Th. van Deursen, Bavianen en slijkgeuzen. Kerk en kerkvolk ten tijde van Maurits en Oldenbarnevelt (Assen, 1974); W. van 't Spijker a.o. (eds.) De Synode van Dordrecht in 1618 en 1619 (Houten, 1987), p. 3848.

${ }^{25}$ J.N. Bakhuizen van den Brink, De Nederlandsche belijdenisgeschriften (Amsterdam, 1940), p. 89.

${ }^{26}$ John Calvin, Institutes, Book III, Chapter 21, cf. E.P. Meijering, Calvin wider die Neugierde. Ein Beitrag zum Vergleich zwischen reformatorischem und patristischem Denken (Nieuwkoop, 1980).
} 
foremost decreed to elect some and declare others reprobate. Only subsequently would He have decided to allow Adam to fall and to let Christ atone for the sins of the elect. ${ }^{27}$ Both these varieties of Reformed teaching leave the initiative entirely with God and deny that Christ died for all of humanity.

Considering that ultimately these views could be construed in ways that made God the 'author of sin', a third option developed, which would become the Remonstrant position. Here it was argued that God, again from eternity, had foreseen the Fall and decreed the atonement of Christ. Unlike the previous options, this one held that God had foreseen that some would accept the saving grace He offered to all in Christ, and others would not. Based on this foreknowledge, God decreed redemption for the former and damnation for the latter. In this way predestination and the impossibility for man to work his own salvation were maintained, as his eternal fate had been preordained before Creation. For stricter Calvinists, however, this was unacceptable, as judgement was based on foreseen merit, and so did not completely deny human agency. ${ }^{28}$

Around the turn of the century this third option had been explored by Jacobus Arminius, professor of theology at Leiden University. During his lifetime, Arminius had been suspected of unorthodox views, but he had managed to avoid any open confrontation and official censure. After his death, however, his followers faced a hardening opposition. In 1610 sixteen of them presented a petition, or Remonstrance, to the States of Holland, in which they articulated the opposing views. They explained their doubts about the supralapsarian position, protested their adherence to the Reformed tradition and complained about harrassment by theological adversaries. They petitioned the States either to decree toleration of divergent interpretations of the Dutch Confession of Faith, or to convene a National Synod for the purpose of examining and clarifying Reformed doctrine on the points under discussion.

Revision of the Confession had been a long-standing desideratum in the Dutch Reformed Church, but for political reasons the States of Holland had always opposed convening a National Synod. Especially in Holland the Reformed Church and the political authorities were at odds about the church order, more specifically on the procedures for the nomination and election of ministers and members of local consistories. Established practice allowed local magistrates, wielding formal or informal powers of patronage, and often through being themselves members of the consistories, to have considerable influence in this field. Synods insisted on more autonomy for the Church, but time and again they saw their efforts frustrated by the States. In Holland, as in a number of provinces, the Dutch Reformed Church did not have a church order approved both by the Church and the Provincial States, and

\footnotetext{
${ }^{27}$ H.IJ. Groenewegen (ed.), De Remonstrantie op haren driehonderdsten gedenkdag, 1610 - 14 januari - 1910, in de oorspronkelijke vorm uitgegeven, afgebeeld en toegelicht (Leiden, 1910), p. 4 10; also in C. Augustijn a.o. (eds.), Reformatorica. Teksten uit de geschiedenis van het Nederlandse protestantisme (Zoetermeer, 1996), p. 120-122.

${ }^{28}$ Cf. Groenewegen, De Remonstrantie; Peter van Rooden, 'De Synode van Dordrecht', in: N.C.F. van Sas (ed.), Waar de blanke top der duinen (Amsterdam/Antwerp, 1995), p. 57-69.
} 
where provincial church orders were in place, they maintained the prerogatives of secular powers. ${ }^{29}$

The opponents of the signatories of the Remonstrance, who came to be known as Counter-Remonstrants, submitted a petition of their own, in which they accused the Arminians of misrepresentation, not only in the Remonstrance, but above all in the popular polemics that had by this time started to appear. These popular pamphlets concentrated on two counter-intuitive final consequences of the doctrine of unconditional election. The first of these was that innocent infants could be predestined for damnation, and the second that the elect could sin with impunity. The defenders of unconditional election emphatically denied ever teaching any of this from their pulpits. On the contrary, they held that a strictly rational analysis of the key tenets of the faith, such as the doctrines on predestination - but also the Trinity, the dual nature of Christ and salvation - would inevitably yield absurdities. They protested that their adversaries concentrated their attacks on a caricature of their theology. ${ }^{30}$

Remonstrants and Counter-Remonstrants had by this time become party labels in what was no longer an academic dispute. Both sides drew support from factions in government circles, which increasingly coalesced into parties around the persons of stadholder Maurice and landsadvocaat Johan van Oldenbarnevelt. Although these factions differed on national defense and foreign policy as much as on theology, political action to quell the divisions mainly focused on the religious controversies. ${ }^{31}$ In 1614 the Estates of Holland promulgated a Resolution towards the Peace of the Church, formulating the theological common ground of human impotence to attain salvation. Both parties held that God elects those who, by His saving grace, believe and persevere in the faith. Theologians were forbidden to go beyond this point in their biblical exegesis and interpretations of the Confession. ${ }^{32}$ The Resolution could not prevent, however, the hardening of the Counter-Remonstrant opposition to the Arminianism which had become dominant in high government circles in Holland, thereby rejecting further compromise. In March 1616 the States of Holland insisted on the election of ministers by committees in which the magistrate and consistory were represented in equal numbers, in an attempt to break the consolidation of the Counter-Remonstrant party. ${ }^{33}$

Landsadvocaat Van Oldenbarnevelt was the prime mover in this policy of confrontation which sought to prevent a schism in the public Reformed Church and

\footnotetext{
${ }^{29}$ Schöffer, 'Crisis', p. 12.

${ }^{30}$ Schriftelicke conferentie, gehouden in 's-Gravenhage inden jare 1611, tusschen sommighe kerckendienaren, aengaende de godlicke praedestinatie metten aencleven vandien ('s-Gravenhage, 1612), p. 20-23, also in Augustijn, Reformatorica, 122-124.

${ }^{31}$ Schöffer, 'Crisis', p. 30-35 and passim; Van Deursen, Maurits, p. 234-251.

${ }^{32}$ Israel, Dutch Republic, p. 430-432; Van Deursen, Bavianen en slijkgeuzen, p. 260-263; Den Tex, Oldenbarnevelt, vol. 3, p. 298-301.

${ }^{33}$ Van Deursen, Bavianen en slijkgeuzen, p. 263-268.
} 
the body politic. The controversies during the Truce increasingly became centered on the landsadvocaat and a close circle of his supporters in high places. When in July 1617 stadholder Maurice ostentatiously attended a Counter-Remonstrant church service in The Hague, he thereby formally distanced himself from this policy. The socalled Sharp Resolution of the States of Holland, authorising city magistrates to recruit armed militias, was a step towards further escalation. The stadholder's coup in 1618, when he replaced the magistrates of cities dominated by Van Oldenbarnevelt's partisans, and the following trial and execution of the landsadvocaat himself, ended the conflict before it could erupt into civil war. After that, the National Synod convened at Dordrecht in 1618-1619 condemned Arminianism and formulated its doctrine on election and grace in the famous Canons of Dordrecht, which together with the Dutch Confession and the Heidelberg Catechism would henceforth form the credal statements of the Dutch Reformed Church. ${ }^{34}$

\section{Reverend rhetoricians?}

In the summer of 1616, when the chambers of rhetoric convened in Vlaardingen, both the landsadvocaat and the stadholder still kept aloof from the controversies that troubled the Church. Oldenbarnevelt's policy was to prevent schism, and the stadholder concurred. ${ }^{35}$ The theological gist of the controversies was highly arcane and the conflicts surrounding the church order may not have been a matter of popular concern. How then did the rhetoricians tackle these matters?

Most outspoken are the plays of Rotterdam and, again, Gorcum. The chamber of Rotterdam has the character United Country deliver a lengthy monologue on Dutch religious diversity, a topic not found in any of the other plays. She relates how the tolerated churches are at peace, they obey the authorities which protect them and dutifully pay their taxes. Diversity is thus not the reason for the religious strife that disturbs her. On the contrary, it is the public Church that foments discord. Wise Council and True Minister tell the audience how human curiosity and intellectual pride have tempted theologians to search the divine mysteries. This has led them astray from true Christianity, which consists in wholeheartedly loving God and one's neighbour. Consequently, instead of keeping the peace and edifying the people, they incite hatred. Ultimately, however, the divisions in the Church derive from ambition, greed and worldly favours, unbecoming in ministers of Christ. ${ }^{36}$ The chamber of Rotterdam seems to allude here to the patronage involved in ecclesiastical careers, which intimately connected the clergy to a political elite increasingly riddled by factionalism.

While Rotterdam and Gouda see it as a responsibility of the ministers to restore and maintain peace, the chamber of Gorcum states that these are so hopelessly divided

\footnotetext{
${ }^{34}$ W. van 't Spijker a.o., Synode van Dordrecht.

${ }^{35}$ Israel, Dutch Republic, p. 433-434.

${ }^{36}$ Redenryck-bergh, fol. Hh4r-Ii2v.
} 
that secular authorities need to step in. In a snappy dialogue the character True Minister convinces Suspicion and Vigilance, the watchdogs of High Authority and Good Government representing the States General and the stadholder, that secular authorities do not overstep their jurisdicion in taking ecclesiastical matters in hand. On the contrary, when the ministers of the Church are at odds, High Authority is beholden, even by divine precept, to restore order. With remarkable foresight, the brothers of Gorcum make True Minister plead for a national Synod to decide the doctrinal conflict. ${ }^{37}$

On the whole, however, the plays are very reticent in their treatment of the theological and ecclesiological controversies. Unlike today, theology and church government apparently were not topics fit for free public discussion. The only aspects touched upon, and then very lightly, are the pragmatic question of whether political power can be used to end the conflict, and the use of the general factionalism of this period to further ecclesiastical careers. There is no attempt to discredit either one theological position or the other, and even the caricatures drawn in popular polemics are completely lacking.

The chambers of Maasland, Ketel and Nootdorp hardly mention the theological controversies at all, and limit themselves to the political and economical ambiguities inherent in the Truce. All other plays do mention the division in the Church, but only in the most general of terms. Even more so than in the case of the respective merits of peace, truce or war, they simply extol the virtue of concord. Love of God and love of one's country should go hand in hand. In its most outspoken form this sentiment is expressed by The Sweet-Briar of Amsterdam. Here the character Wisdom exhorts the play's protagonist Ruler to protect religion, as the springwell of all human societies and the principal bond of harmony in any commonwealth. ${ }^{38}$

The ideal society

Besides arguments on the benefits of peace or war, sporadic acclaim for either the stadholder or the landsadvocaat, and reflections on religion as the principal element of social cohesion, the plays at this festival express conceptions of the ideal society. These usually surface at the end of the plays, in the elaboration on the answer of each chamber on the question posed by their hosts. The ideal society is hierarchically structured and derives its legitimacy from God. Rights and duties are sharply defined according to rank and status. ${ }^{39}$

The play of Gouda presents a Disunited People that has lost its Five Senses. Through the good offices of Theologian, it is converted into a sensible United People. At the end of the play High Authority, Lawful magistrate and Theologian conclude the argument presented by the chamber: Godly Government creates Harmony, and

\footnotetext{
${ }^{37}$ Redenryck-bergh, fol. Vv2v.

${ }^{38}$ Redenryck-bergh, fol. M1r.

${ }^{39}$ Cf. William Doyle, The Ancien Regime (Basingstoke and London, 1986).
} 
together they protect the People. Examples of this can be found in biblical history, in Gideon with his trusted band, Joshua, David and the Maccabees. The four classical virtues Justice, Moderation, Prudence and Fortitude concur that without Harmony they are powerless. Once this is clear, Fear of Perdition is dispelled and Happiness evoked in its stead. The order of appearance of the allegorical personages suggests a structure in which Godly Government, itself hierarchically composed of High Authority, Lawful Magistrate and Theologian, is placed above the People, which in turn is supported by the four virtues. ${ }^{40}$

All chambers except those of Zoetermeer, Nootdorp and Dordrecht, Haarlem's White Carnations and Amsterdam's White Lavender, included a personification of secular government in their casts, either as one character, or in a number of hierarchically ordered characters representing separate ranks or aspects of government. Their prime responsibility is the well-being of the people and the prosperity of the country. In comparison, clergy is far less prominent. Most plays, although they sing the praise of true religion as the cement of society, do not present the ministry as part of the ideal social order. The play of Dordrecht even contains two allegorical figures, Erudite Conceit and Boundless Zeal, who represent the divisive capacities of religion by arguing in favour of religious coercion and persecution of heresy. Eventually they turn out to be Catholic theologians 'from Louvain', advocating the exact opposite of what true ministers should preach, that is: God's goodness, contrition and redemption. ${ }^{41}$

Only the chambers of Rotterdam, Gouda and Gorcum cast a Reformed minister or theologian. In the play of Gouda, Theologian, as part of the leading elite, has a major role as a mediator between government and people. The character True Minister is less prominent $\mathrm{n}$ Rotterdam's performance. As the curtain rose for the the last act, the audience saw the populace sitting on the stage. True Minister ranked first among them, before the people and the civic virtues. ${ }^{42}$ The hierarchical sequence here is the same as in Gouda's play: government - clergy - people - virtues, only here the minister is not part of government, but simply a paid civil servant, and thus a subject.

The plays thus mirror the social hierarchies of the Ancien Régime, but for all that they do not simply affirm a top-down power structure. Some plays allude to the biblical metaphor of society as a body made up of many members, some honourable and others less so, but each necessary for the well-being of the whole. Most outspoken was the chamber of Rotterdam, which blamed the current discord on vain curiosity towards the divine mysteries as well as on the endemic factional rivalry whereby powerful families gathered power and wealth for themselves and their clients, to the exclusion of all others. Such rivalry is harmful for the body of society. By contrast, the chamber sketches an ideal society in which the rich support the poor, as fellow members of one body, for the common good. ${ }^{43}$

\footnotetext{
${ }^{40}$ Redenryck-bergh, fol. Nn3v-Oo2r.

${ }^{41}$ Redenryck-bergh, fol. Eee1r-Eee4r, Fff2r.

${ }^{42}$ Redenryck-bergh, fol. Kk1r.

${ }^{43}$ Redenryck-bergh, fol. Ii2v-Ii3r.
} 
This motif is also found in the plays of Nootdorp and the Schiedam chamber The Fig Tree (De Vijgeboom). Both elaborate on the body metaphor to denounce greed for wealth and power, but also to warn against discord and the revolt of the lower orders against those set in authority over them. In both plays the stomach's greed which consumes all the food and drink, without having to work for it, is resented by the other members: the head which has all the worry, the legs that carry the body, and the hands that do all the work. Self-involved dissension among the members, however, will inevitably destroy the body. The body cannot revolt against the stomach. All members are equally necessary and have to support each other. Only by providing the stomach with food can the health of the body as a whole be maintained, and this in turn is the proper task of the stomach. ${ }^{44}$

Where in most histories of the Twelve Years' Truce the theological controversies take pride of place, these plays seem far more concerned with a just division of the economic benefits the suspension of open warfare had brought. The use of the body metaphor in the plays of Schiedam and Nootdorp echoes the dialogue between the farmer, the man of independent means and the city-dwellers in the play of the Amsterdam chamber The White Lavender, in which the former two could boast increasing prosperity, whereas the latter had fallen on hard times through lack of work. Recently Jonathan Israel has argued that industrial centres, among which Schiedam can be counted, experienced an economic slump during the Truce, suggesting that disaffected masses of the working poor played a prominent part in the tide of popular unrest during the years 1617 and $1618 . .^{45}$

The concept of an ideal, hierarchically ordered society, with mutual obligations between higher and lower ranks all contributing towards the common good, seamlessly meshes with the topics addressed in the poems (refereinen) which the chambers had to present on the question: 'What do children, once grown up, owe a parent who has raised them properly?' The answers of the various chambers are virtually in unison and relatively predictable. Children owe a conscientious parent respect, obedience, gratitude, and, above all, love.

Limited as it is, the answers do show some variation. Most chambers emphasise the religious nature of these childish virtues, and adduce biblical examples of filial respect, obedience, gratitude and love. Some use models from classical literature and from nature alongside biblical material. Some of the poems, however, broaden the scope of the question beyond the relationship between parents and their offspring, to a more general treatment of hierarchical relations. The White Carnations from Haarlem liken proper parental guidance to God's providence towards humanity: a loving form of discipline, neither cruel nor soft. The chamber of Delft and Schiedam's The FigTree compare the loving obedience of children towards their parents to the duties of subjects to secular authorities. ${ }^{46}$ In line with the over-all scant representation of clergy only one chamber, that of Zoetermeer, mentions ministers among those in authority. ${ }^{47}$

\footnotetext{
${ }^{44}$ Redenryck-bergh, fol. Pp4v, Iii4v-Kkk1r.

${ }^{45}$ Israel, Dutch Republic, p. 437.

${ }^{46}$ Redenryck-bergh, fol. Z2r, Kkk3r.

${ }^{47}$ Redenryck-bergh, fol. Cc4r.
} 


\section{Conclusion}

How are the political and religious choices, that confronted the Dutch Republic in 1616 , represented in these plays and poems? Political and religious controversies are commented upon, although mostly in very general terms. Of the fifteen plays presented, several elaborate on the ambiguities inherent in the Truce. Only two, those of Maasland and Gorcum, explicitly name the political protagonists in the troubles, praising them as great men. The religious controversy is addressed in veiled terms only. It is generally lamented, as religion should be the cement of society, but neither the disputed points nor even the names of the contesting parties are mentioned. Some plays show concern about factional powerplay and the uneven distribution of increasing economic prosperity.

None of the chambers presumes to propose any practical proposal to offer other than making a plea for concord. The image of a well-ordered society, in which good government maintains discipline in ways that command respect and love from those governed, most pointedly presented in the use of the body metaphor and the poems on filial duty, supports this general message. This is the context in which the political, economic and religious controversies have their place. They are mentioned, but none of the plays show much interest in the main protagonists of the developing conflicts, nor their actual programs. There is no actual discussion.

How then, does all this fit the functions of the Chambers of Rhetoric, as recent scholarship presents it? Can plays like these be said to be a contribution to a public debate, or even the formation of a climate of public opinion? On the basis of the printed texts, it is hard to fathom what impression the series of performances made on the audience. We cannot even be certain who were in this audience. The plays were staged in the open air, in a public place, but would a rhetorician's festival attract the average Vlaardingen inhabitant? The literary style is stilted, the message highly conventional. Decorations and costume, the rhetorical quality of delivery and gesture certainly must have had entertainment value. Prizes were awarded for these aspects.

As for the reception of the message, we can only look at the prizes for the morality plays. First and second prizes went to the chambers of Gorcum and Maasland, which explicitly praised either the stadholder or the landsadvocaat. This outspokenness may have been valued, even though praise for one political leader did not amount to blame for the other. Third and fourth prize fell to the plays of Zoetermeer and Dordrecht. These do not relate their message clearly to actual political, economic or religious questions, but voice a general criticism of the hedonism and self-centeredness of their contemporaries. Both give the same pious answer to the question posed by their hosts: what the country needs is ardent prayer, refraining from sin and a simple Christian life.

On the whole, it is hard to see how the brothers could have invited public discussion through their performances. The plays certainly show concern for public affairs, but they studiously avoid taking a clear position. They fall considerably short of Van Dixhoorn's description; they do not seem to have provided the audience with arguments for further discussion, or towards individual points of view. They do not 
elaborate or even mention the possible options, let alone compare alternatives. Discord is blamed on the greed of ruling factions for wealth and power, and the loosely related factionalism in the Church. Their criticism is, however, thickly veiled in metaphor. The plays do not contribute to a public debate in the current or any other meaning of that term. Perhaps a public sphere, or even the beginning thereof, should not really be expected early in the seventeenth century. As mild as censorship may have been in the Dutch Republic, compared with the European situation in general, open and free criticism of the political elite and/or the public Church by commoners was suppressed. ${ }^{48}$

The rhetoricians' plays and festivals rather resemble rituals, meant to create and celebrate concord. The rhetorical mastery aspired to in the chambers of rhetoric, and demonstrated in the morality plays, was directed precisely at this ritual function. Van Dixhoorn and others have convincingly argued that the chambers were schools of vernacular rhetoric, offering an education in the skills needed for a variety of public functions. ${ }^{49}$ Whereas academic theological and legal training taught the formulation and defence of adversarial positions, the vernacular rhetorical skills polished in the chambers may well have aimed at a totally different goal.

The backbone of the 'culture of discussion' in the multifarious councils, boards and committees of early modern Dutch society, as described by Marijke Spies and Willem Frijhoff, was building and reaching consensus. ${ }^{50}$ Problems had to be addressed and decisions formulated, in terms that could satisfy all involved and enabled them to present a unified front outwards. This was not a public process, but it took place behind the closed doors of said councils, boards and committees. To teach this balancing act, getting things done without undue antagonism, conjuring up harmony and concord with the magic of word and gesture, if possible in a playful mood, even, or especially, in times of sharp discord, was the core business of the chambers of rhetoric.

Voetnoten webstyle, maar 10 punts, single line

Pagenumbers, header, central

\footnotetext{
${ }^{48}$ S. Groenveld, 'The Mecca of authors? States Assemblies and Censorship in the Seventeenth-Century Dutch Republic', in: A.C. Duke and C.A. Tamse (eds.), Too Mighty to be Free. Censorship and the Press in Britain and The Netherlands (Zutphen, 1987), 63-86.

${ }^{49}$ Van der Heijden and Van Boheemen, Met minnen versaemt; Van Dixhoorn, Lustige geesten.

${ }^{50}$ Frijhoff and Spies, 1650 , p. 218-219.
} 